\title{
Palladium-Catalyzed Cross-Coupling Reactions with Zn, B, and In Exhibiting High Turnover Numbers (TONs): Use of Bidentate Phosphines and Other Critical Factors in Achieving High TONs
}

\author{
Zhihong Huang, Mingxing Qian, David J. Babinski, Ei-ichi Negishi* \\ Herbert C. Brown Laboratories of Chemistry, Purdue University, 560Oval Drive, West Lafayette, \\ Indiana 47907-2084
}

General. All experiments were conducted under argon atmosphere. THF was dried and distilled by the standard method. $\mathrm{ZnBr}_{2}$ was flame-dried under vacuum prior to use. $\mathrm{Pd}(\mathrm{DPEPhos}) \mathrm{Cl}_{2}$ was prepared according to the literature procedure. ${ }^{[\mathrm{a}]} \mathrm{Pd}(\mathrm{dppf}) \mathrm{Cl}_{2}$ was purchased from Strem.

Flash chromatographic separations were carried out on 230 - 400 mesh silica gel 60. Gas chromatography was performed on an HP 6890 Gas Chromatograph using a HP-5 capillary column $(30 \mathrm{~m} \times 0.32 \mathrm{~mm}, 0.5 \mu \mathrm{m}$ film $)$ with appropriate hydrocarbons as internal standards. ${ }^{1} \mathrm{H}$ and ${ }^{13} \mathrm{C} \mathrm{NMR}$ spectra were recorded in $\mathrm{CDCl}_{3}$ on a Varian Inova300 spectrometer.

\section{Pd-Catalyzed Cross-Coupling of Aryl- or Alkenylzincs with Aryl or Alkenyl Iodides.} Representative Procedure A. 4-Methyl-biphenyl. ${ }^{[\mathrm{b}]}$ To iodobenzene (245 mg, 1.2 mmol) in THF (2 mL) cooled to $-78{ }^{\circ} \mathrm{C}$ was added $t$-BuLi $(1.41 \mathrm{~mL}, 1.7 \mathrm{M}$ in hexane, 2.4 mmol). The resultant solution was stirred for $30 \mathrm{~min}$ at $-78{ }^{\circ} \mathrm{C}$, followed by addition of a solution of dry $\mathrm{ZnBr}_{2}(270 \mathrm{mg}, 1.2 \mathrm{mmol})$ in THF $(1 \mathrm{~mL})$. After the mixture thus obtained had been stirred for $5 \mathrm{~min}$ at $-78{ }^{\circ} \mathrm{C}$ and warmed to $0{ }^{\circ} \mathrm{C}$ over $25 \mathrm{~min}$, 4-methyliodobenzene $(218 \mathrm{mg}, 1 \mathrm{mmol})$ and $\mathrm{Pd}(\mathrm{dppf}) \mathrm{Cl}_{2}\left(1 \times 10^{-4} \mathrm{M}, 100 \mathrm{uL}, 1 \times 10^{-5} \mathrm{mmol}\right.$ in THF) were added at $23{ }^{\circ} \mathrm{C}$. The resultant mixture was stirred at $23{ }^{\circ} \mathrm{C}$ and monitored by GLC analysis. After $20 \mathrm{~h}$, GLC analysis indicated that the starting material had been completely consumed and that the title compound was formed in 97\% GLC yield. The reaction mixture was quenched with $1 \mathrm{M} \mathrm{HCl}$, extracted with ether, washed with aqueous $\mathrm{NaHCO}_{3}$, dried over $\mathrm{MgSO}_{4}$, filtered and concentrated. Flash chromatography (silica gel, 
hexane) afforded the title compound $162 \mathrm{mg}(96 \%):{ }^{1} \mathrm{H}$ NMR $\left(300 \mathrm{MHz}, \mathrm{CDCl}_{3}\right) \delta 2.36$ (s, $3 \mathrm{H}), 7.21(\mathrm{~d}, J=7.9 \mathrm{~Hz}, 2 \mathrm{H}), 7.28(\mathrm{t}, J=7.3 \mathrm{~Hz}, 1 \mathrm{H}), 7.39(\mathrm{t}, J=7.3 \mathrm{~Hz}, 2 \mathrm{H}), 7.47$ $(\mathrm{d}, J=7.9 \mathrm{~Hz}, 2 \mathrm{H}), 7.55(\mathrm{~d}, J=7.8 \mathrm{~Hz}, 2 \mathrm{H}) ;{ }^{13} \mathrm{C} \mathrm{NMR}\left(75 \mathrm{MHz}, \mathrm{CDCl}_{3}\right) \delta 21.06$, 126.94 (3C), 126.96 (2C), 128.69 (2C), 129.46 (2C), 136.95, 138.32, 141.12.

(E)-1-Phenyl-1-octene. ${ }^{[c]}$ The title compound was prepared according to Representative Procedure A. Yield: 97\%, ${ }^{1} \mathrm{H}$ NMR $\left(300 \mathrm{MHz}, \mathrm{CDCl}_{3}\right) \delta 0.87(\mathrm{t}, J=6.6 \mathrm{~Hz}, 3 \mathrm{H}), 1.25$ 1.45 (m, 8 H), 2.44 (m, 2 H), $6.43(\mathrm{~m}, 1 \mathrm{H}), 6.61$ (d, $J=15.8 \mathrm{~Hz}, 1 \mathrm{H}), 7.35-7.60(\mathrm{~m}, 5$ $\mathrm{H}) ;{ }^{13} \mathrm{C}$ NMR $\left(75 \mathrm{MHz}, \mathrm{CDCl}_{3}\right) \delta 14.34,22.90,29.19,29.62,32.03,33.31,126.13$ (2C), $126.93,128.65$ (2C), 129.98, 131.33, 138.19 .

\section{Pd-Catalyzed Cross-Coupling of Alkynylzincs with Alkenyl or Aryl Iodides.} Representative Procedure A. 1-Phenyl-dec-3-en-1-yne. ${ }^{[\mathrm{d}]}$ To phenylacetylene (123 mg, $1.2 \mathrm{mmol})$ in THF $(4 \mathrm{~mL})$ cooled to $-78{ }^{\circ} \mathrm{C}$ was added $n$-BuLi $(0.48 \mathrm{~mL}, 2.5 \mathrm{M}$ in hexane, $1.2 \mathrm{mmol})$. The resultant solution was stirred for $30 \mathrm{~min}$ at $-78{ }^{\circ} \mathrm{C}$. followed by addition of a solution of dry $\mathrm{ZnBr}_{2}(270 \mathrm{mg}, 1.2 \mathrm{mmol})$ in THF $(1 \mathrm{~mL})$. After the mixture thus obtained had been stirred for $5 \mathrm{~min}$ at $-78{ }^{\circ} \mathrm{C}$ and warmed to $0{ }^{\circ} \mathrm{C}$ over $25 \mathrm{~min},(E)-1$ iodo-octene (238 mg, $1.0 \mathrm{mmol})$ and $\mathrm{Pd}(\mathrm{DPEphos}) \mathrm{Cl}_{2}\left(1 \times 10^{-4} \mathrm{M}, 100 \mathrm{uL}, 1 \times 10^{-5}\right.$ mmol in THF) were added at $23{ }^{\circ} \mathrm{C}$. The resultant mixture was stirred at $23{ }^{\circ} \mathrm{C}$ and monitored by GLC analysis. After $10 \mathrm{~h}$, GLC analysis indicated that the starting material had been completely consumed and that the title compound was formed in $99 \%$ yield. The reaction mixture was quenched with aqueous $\mathrm{NH}_{4} \mathrm{Cl}$, extracted with ether, washed with aqueous $\mathrm{NaHCO}_{3}$, dried over $\mathrm{MgSO}_{4}$, filtered and concentrated. Flash chromatography (silica gel, hexane) afforded the title compound $204 \mathrm{mg}(96 \%):{ }^{1} \mathrm{H}$ NMR $\left(300 \mathrm{MHz}, \mathrm{CDCl}_{3}\right) \delta 0.88(\mathrm{t}, J=5.9 \mathrm{~Hz}, 3 \mathrm{H}), 1.2-1.4(\mathrm{~m}, 8 \mathrm{H}), 2.11(\mathrm{dt}, J=7.0$ and 14.0 $\mathrm{Hz}, 2 \mathrm{H}), 5.64(\mathrm{~d}, J=15.8 \mathrm{~Hz}, 1 \mathrm{H}), 6.19(\mathrm{dt}, J=7.0$ and $15.8 \mathrm{~Hz}, 1 \mathrm{H}), 7.2-7.4(\mathrm{~m}, 5 \mathrm{H})$; ${ }^{13} \mathrm{C} \mathrm{NMR}\left(75 \mathrm{MHz}, \mathrm{CDCl}_{3}\right) \delta 14.02,22.57,28.70,28.77,31.64,33.17,87.83,88.35$, 109.51, 123.65, 127.72, 128.14 (2C), 131.32 (2C), 145.02.

1-Phenyl-dec-3-en-1-yne. The title compound was prepared according to Representative Procedure A except $2 \times 10^{-7} \mathrm{mmol} \mathrm{Pd}(\mathrm{DPEphos}) \mathrm{Cl}_{2}$ was used. The reaction mixture was refluxed $24 \mathrm{~h}$, the title compound was formed in $75 \%$ GLC yield. 
1-Phenyl-1-octyne. ${ }^{[\mathrm{e}]}$ The title compound was prepared according to Representative Procedure A except 1-octyne and iodobenzene were used. Yield: 96\%; ${ }^{1} \mathrm{H}$ NMR (300 $\left.\mathrm{MHz}, \mathrm{CDCl}_{3}\right) \delta 0.89(\mathrm{t}, J=6.6 \mathrm{~Hz}, 3 \mathrm{H}), 1.2-1.6(\mathrm{~m}, 8 \mathrm{H}), 2.36(\mathrm{t}, J=6.9 \mathrm{~Hz}, 2 \mathrm{H}), 7.1-$ $7.4(\mathrm{~m}, 5 \mathrm{H}) ;{ }^{13} \mathrm{C}$ NMR $\left(75 \mathrm{MHz}, \mathrm{CDCl}_{3}\right) \delta 14.10,19.48,22.68,28.71,28.86,31.49$, $80.73,90.40,124.31,127.43,128.18$ (2C), 131.59 (2C).

1-Phenyl-1-octyne. The title compound was prepared according to Representative Procedure A except 1-octyne, iodobenzene, and $5 \times 10^{-7} \mathrm{mmol} \mathrm{Pd}(\mathrm{DPEphos}) \mathrm{Cl}_{2}$ were used. The reaction mixture was refluxed $24 \mathrm{~h}$, the title compound was formed in $82 \%$ GLC yield.

\section{Pd-Catalyzed Sonogashira Cross-Coupling of Phenylacetylene with (E)-1-Iodo-1-} octene. Representative Procedure B. 1-Phenyl-dec-3-en-1-yne. To a solution of phenylacetylene $(123 \mathrm{mg}, 1.2 \mathrm{mmol})$ and $(E)$-1-iodo-octene $(238 \mathrm{mg}, 1.0 \mathrm{mmol}) \mathrm{in}_{\mathrm{Et}} \mathrm{NH}$ was added $1 \times 10^{-3} \mathrm{mmol} \mathrm{Pd}(\mathrm{DPEphos}) \mathrm{Cl}_{2}$ and $\mathrm{CuI}(19 \mathrm{mg}, 0.1 \mathrm{~mol})$. The reaction mixture was stirred at $23{ }^{\circ} \mathrm{C}$ for $10 \mathrm{~h}$, the title compound was formed in $92 \%$ GLC yield. 1-Phenyl-dec-3-en-1-yne. The title compound was prepared according to Representative Procedure B except $1 \times 10^{-5} \mathrm{mmol} \mathrm{Pd}(\mathrm{DPEphos}) \mathrm{Cl}_{2}$ was used. The reaction mixture was refluxed $24 \mathrm{~h}$, the title compound was formed in 32\% GLC yield.

1-Phenyl-dec-3-en-1-yne. The title compound was prepared according to Representative Procedure $\mathrm{B}$ except $\mathrm{Cs}_{2} \mathrm{CO}_{3}(652 \mathrm{mg}, 2.0 \mathrm{mmol})$, THF, and $1 \times 10^{-5} \mathrm{mmol}$ $\mathrm{Pd}(\mathrm{DPEphos}) \mathrm{Cl}_{2}$ were used. The reaction mixture was refluxed $24 \mathrm{~h}$, the title compound was formed in 56\% GLC yield.

\section{Pd-Catalyzed Stille Cross-Coupling of Tributylphenylethynyltin with (E)-1-Iodo-1-} octene. 1-Phenyl-dec-3-en-1-yne. To phenylacetylene (123 mg, $1.2 \mathrm{mmol})$ in THF (4 $\mathrm{mL})$ cooled to $-78{ }^{\circ} \mathrm{C}$ was added $n$ - $\mathrm{BuLi}(0.48 \mathrm{~mL}, 2.5 \mathrm{M}$ in hexane, $1.2 \mathrm{mmol})$. The resultant solution was stirred for $30 \mathrm{~min}$ at $-78{ }^{\circ} \mathrm{C}$, followed by addition of $\mathrm{Bu}_{3} \mathrm{SnCl}$ (391 $\mathrm{mg}, 1.2 \mathrm{mmol}$ ). After the mixture thus obtained had been stirred for $5 \mathrm{~min}$ at $-78{ }^{\circ} \mathrm{C}$ and warmed to $0{ }^{\circ} \mathrm{C}$ over $25 \mathrm{~min},(E)$-1-iodo-octene $(238 \mathrm{mg}, 1.0 \mathrm{mmol})$ and $\mathrm{Pd}(\mathrm{DPEphos}) \mathrm{Cl}_{2}$ (35 mg, $0.05 \mathrm{mmol}$ ) were added at $23{ }^{\circ} \mathrm{C}$. The resultant mixture was stirred at $23{ }^{\circ} \mathrm{C}$ and 
monitored by GLC analysis. After $10 \mathrm{~h}$, GLC analysis indicated that the starting material had been completely consumed, and the title compound was formed in $85 \%$ yield.

Pd-Catalyzed Cross-Coupling of Phenylethynylmanganese Chloride with (E)-1Iodo-1-octene. 1-Phenyl-dec-3-en-1-yne. To phenylacetylene (123 mg, $1.2 \mathrm{mmol})$ in THF $(4 \mathrm{~mL})$ was added $\mathrm{MeMgBr}(0.40 \mathrm{~mL}, 3.0 \mathrm{M}$ in ethyl ether, $1.2 \mathrm{mmol})$ at $23{ }^{\circ} \mathrm{C}$. The mixture was stirred at $23{ }^{\circ} \mathrm{C}$ for $3 \mathrm{~h}$, followed by addition of $\mathrm{MnCl}_{2}(151 \mathrm{mg}, 1.2 \mathrm{mmol})$ in THF $(2 \mathrm{~mL})$ at $0{ }^{\circ} \mathrm{C}$. The mixture thus obtained was stirred at $0{ }^{\circ} \mathrm{C}$ for $30 \mathrm{~min},(E)-1-$ iodo-octene (238 mg, $1.0 \mathrm{mmol})$ and $\mathrm{Pd}(\mathrm{DPEphos}) \mathrm{Cl}_{2}(35 \mathrm{mg}, 0.05 \mathrm{mmol})$ were added at $0{ }^{\circ} \mathrm{C}$. The resultant mixture was stirred at $23{ }^{\circ} \mathrm{C}$ and monitored by GLC analysis. After 10 h, GLC analysis indicated that the starting material had been completely consumed, and the title compound was formed in $92 \%$ yield.

Pd-Catalyzed Cross-Coupling of Phenylethynylmagnesium Bromide with (E)-1Iodo-1-octene. 1-Phenyl-dec-3-en-1-yne. To phenylacetylene (123 mg, $1.2 \mathrm{mmol})$ in THF $(4 \mathrm{~mL})$ was added $\mathrm{MeMgBr}(0.40 \mathrm{~mL}, 3.0 \mathrm{M}$ in ethyl ether, $1.2 \mathrm{mmol})$ at $23{ }^{\circ} \mathrm{C}$. The mixture thus obtaibe had been stirred at $23{ }^{\circ} \mathrm{C}$ for $3 \mathrm{~h},(E)$-1-iodo-octene $(238 \mathrm{mg}, 1.0$ mmol) and $1 \times 10^{-3} \mathrm{mmol} \mathrm{Pd}(\mathrm{DPEphos}) \mathrm{Cl}_{2}$ were added at $23{ }^{\circ} \mathrm{C}$. The reaction mixture was stirred at $23{ }^{\circ} \mathrm{C}$ for $24 \mathrm{~h}$, the title compound was formed in $85 \%$ GLC yield.

\section{Pd-Catalyzed Cross-Coupling of 1-(B-Methoxy-9-BBN)-2-Phenyl-ethynye with $(E)$ -} 1-Iodo-1-octene. 1-Phenyl-dec-3-en-1-yne. To phenylacetylene (123 mg, $1.2 \mathrm{mmol})$ in THF ( $4 \mathrm{~mL}$ ) was added potassium $(47 \mathrm{mg}, 1.2 \mathrm{mmol})$ at $23{ }^{\circ} \mathrm{C}$. The mixture was stirred at $23{ }^{\circ} \mathrm{C}$ for $4 \mathrm{~h}$, followed by addition of $B$-MeO-9-BBN (1.2 mL, $1.0 \mathrm{M}$ in THF, $1.2 \mathrm{mmol}$ ) at $0{ }^{\circ} \mathrm{C}$. The reaction mixture thus obtained had been stirred at $0{ }^{\circ} \mathrm{C}$ for $30 \mathrm{~min},(E)-1$ iodo-octene (238 mg, $1.0 \mathrm{mmol})$ and $1 \times 10^{-3} \mathrm{mmol} \mathrm{Pd}(\mathrm{DPEphos}) \mathrm{Cl}_{2}$ were added at 0 ${ }^{\circ} \mathrm{C}$. The reaction mixture was stirred at $23{ }^{\circ} \mathrm{C}$ for $10 \mathrm{~h}$, the title compound was formed in 93\% GLC yield.

Pd-Catalyzed Cross-Coupling of Triphenylethynylindium with (E)-1-Iodo-1-octene. 
1-Phenyl-dec-3-en-1-yne. To phenylacetylene (123 mg, $1.2 \mathrm{mmol})$ in THF (4 mL) cooled to $-78{ }^{\circ} \mathrm{C}$ was added $n$-BuLi $(0.48 \mathrm{~mL}, 2.5 \mathrm{M}$ in hexane, $1.2 \mathrm{mmol})$ at $-78{ }^{\circ} \mathrm{C}$. The resultant solution was stirred for $30 \mathrm{~min}$. at $-78{ }^{\circ} \mathrm{C}$, followed by addition of $\mathrm{InCl}_{3}(90$ $\mathrm{mg}, 0.41 \mathrm{mmol}$ ) at $-78{ }^{\circ} \mathrm{C}$. After the mixture thus abtained had been stirred for $5 \mathrm{~min}$. at $78{ }^{\circ} \mathrm{C}$ and then warmed to $0{ }^{\circ} \mathrm{C}$ over $25 \mathrm{~min} .,(E)-1$-iodo-octene $(238 \mathrm{mg}, 1.0 \mathrm{mmol})$ and $\operatorname{Pd}($ DPEphos $) \mathrm{Cl}_{2}\left(1 \times 10^{-3} \mathrm{mmol}\right.$ in THF $)$ were added at $23{ }^{\circ} \mathrm{C}$. The resultant mixture was stirred at $23{ }^{\circ} \mathrm{C}$ and monitored by GLC analysis. After $10 \mathrm{~h}$, GLC analysis indicated that the starting material had been completely consumed, and the title compound was formed in $93 \%$ yield.

[a] van der Burgt, Y. E. M.; Kamer, P. C. J.; van Leeuwen, P. W. N. M. Organometallics 1995, 14, 3081.

[b] Lee, P. H.; Lee, S. W.; Seomoon, D. Org. Lett. 2003, 5, 4963.

[c] Kikukawa, K.; Maemura, K.; Kiseki, Y.; Wada, F.; Matsuda, T. J. Org. Chem. 1981, 46,4885 .

[d] Anastasia, L. Negishi, E. Org. Lett. 2001, 3, 3111.

[e] Okuro, K.; Furuune, M.; Enna, M.; Miura, M.; Nomura, M. J. Org. Chem. 1993, 58, 4716. 